\title{
Investigating the Islamic and Conventional Mutual Fund Performance: Evidence From Malaysia Equity Market
}

\author{
Shaliza Alwi, Rosimah Ahmad, Irma Zura Amir Hashim, Norbaizura Mohd Naim \\ Taylor's University, Subang Jaya, Malaysia
}

\begin{abstract}
The phenomena of financial crisis (2007-2008) shows a significant breakdown of US\$16 trillion in conventional financial industry. This provides an opportunity for Islamic capital market to drive the global asset growth investments to investors. Previous studies signal mixture results on Islamic mutual fund (IMF) and conventional mutual fund (CMF) performance. This study aims to analyze the performance of 200 IMFs and CMFs from 2007 to 2015. The sub-sample period of 2007 to 2015 will be compared to the era of financial crisis from 2007-2008. Findings show all types of mutual funds are performed throughout 2007 until 2015. The results provide information that would benefit the investors and market players in asset funds selection.
\end{abstract}

Keywords: equity fund, Islamic mutual funds, coventional mutual funds, performance measurements

\section{Introduction}

\section{Overview}

Mutual fund is used as an investment tool to gather a pool of investment from investors and the mutual fund companies to invest in securities market to create wealth for the investors. The aims of investors are towards portfolio diversifications, liquidity, lower risks, and abnormal return. The origin studies on mutual fund performance are based on the theory of the pricing of capital assets under conditions of risks (Sharpe, 1964; Lintner, 1965; Treynor, 1965). The argument on the predictive ability of portfolio fund's manager to select particularly the mutual fund performance became the main issue in investment activity. In the era 1960s, the phenomenon studies mostly focus on the method of ranking portfolio of mutual fund performance (e.g., Farrar, 1962; Friend \& Vickers, 1965; Horowitz, 1965; Treynor, 1965; Sharpe, 1966; Cohen \& Pogue, 1967). Hence, it is very important the outperformance of the mutual fund and the significant risk in comparisons with other types of mutual fund (Islamic mutual fund versus conventional mutual fund).

\section{Equity Fund}

An equity fund is an open or closed-end fund that invests primarily in stocks, allowing investors to buy into the fund and thus buy a basket of stocks less stressful than they could purchase the individual securities. One of

Shaliza Alwi, Ph.D., Scholar, MBA, (Finance), Faculty of Business and Law, Taylor's University, Subang Jaya, Malaysia. Rosimah Ahmad, Ph.D., Scholar, MBA, (Finance), Faculty of Business and Law, Taylor's University, Subang Jaya, Malaysia. Irma Zura Amir Hashim, M.Sc., (Finance), Faculty of Business and Law, Taylor's University, Subang Jaya, Malaysia.

Norbaizura Mohd Naim, Ph.D., Scholar, MBA, (Mktg), Faculty of Business and Law, Taylor’s University, Subang Jaya, Malaysia. 
the greatest advantages of equity funds is instant diversification. It can pursue income and capital gain or both incomes as well. Furthermore, it is usually easier and less expensive to invest in equity funds than to buy each and every stock in a fund's portfolio. The main advantage of equity funds is instant diversification.

Furthermore, it is classically easier and less expensive to invest in equity funds than to buy each and every stock in a fund's portfolio. Equity funds are also cheaper in such a way to avoid the often higher transaction costs and lower liquidity linked with trading individual stocks. It is frequently easier to sell fund shares than to sell a particular stock, particularly if that stock has unusual characteristics, the issuer has a low credit rating, or the issuer is facing other turmoil. Equity funds also offer the services of a professional who watches and acts on the market on behalf of the investor, handles the trading decisions, and determines the asset. There are a few broad categories of equity funds which are general equity funds include:

- Aggressive growth funds, which seek maximum capital appreciation and may use speculative strategies.

- Small-company funds, which invest in companies with relatively small market capitalizations.

- Growth funds, which invest in larger, established but growing companies. They generally emphasize capital appreciation.

- Growth and income funds, which invest in larger, established companies that offer the potential for capital appreciation but also pay regular dividends.

- Equity-income funds, which primarily invest in dividend-paying stocks. Other equity funds include:

- Hybrid funds, which generally invest in equities but also invest in bonds.

- Specialty funds, which invest in stocks meeting certain criteria (such as geographic region, industry sector, social causes, etc.).

- Sector funds, which invest in specific stock groups, often within one industry.

- Index funds, which invest in the same or similar stocks as equity market indices like the S\&P 500.

- International funds, which invest in foreign stocks.

\section{Islamic Mutual Funds}

The prevalent acceptance of equity investments by shari'ah scholars in the early 1990s fortified the way to promote mutual funds that operate in compliance with the ethical guidelines of the Islamic Law. As a results, the Islamic finance industry has administered worldwide recognition in its effectiveness as a financing facility, even in non-Muslim countries (World Bank, 2017), and this is reflected from the industry's rapid expansion over the past decade-with assets that have doubled in value over the years. The main disparity between conventional mutual fund (CMF) and Islamic mutual fund (IMF) is that IMF has to be shari'ah compliant; it has to obey Islamic laws. Shari'ah provides guidelines for aspects of Muslim life, including religion, politics, economics, banking, business, and law (Silva, 2006). El-Gamal (2000) stated that shari'ah promotes the utilization of partnership strategy and profit sharing, but gharar (uncertainties), maysir (gambling), and riba (interest) are strictly prohibited. The Islamic unit trusts provide investors with access to professional management of funds to maximize returns on different risk profiles. The comprehensiveness of the Islamic financial system creates significant investment opportunities for both Islamic and conventional investors in managing their portfolios to meet financial needs. 


\section{The Phenomenon of Islamic Equity Funds}

The primary Islamic equity funds offered the public in 1993 when the National Commercial Bank in Saudi Arabia decided, with the help of the Wellington Management Company of Boston, Massachusetts, to launch a global equity fund that follows the shari'ah restrictions on investing in shares. Through the joint venture effort of these parties, the first ever Islamic equity fund was launched in January 1995.

\section{The Market Trends}

The development of the Islamic financial industry is certainly assisted by the rapid growth of Islamic mutual funds across the globe and therefore it is crucial to realize the dynamics of its performance consequences and continued progress in the Islamic market. This study aims to address two areas of concern, with the use of empirical evidence; the downside risks associated with adverse economic climate and its impact on Islamic mutual funds, as well as, the costs—if any, associated with investing in Islamic mutual funds the opening of reliable equity benchmarks by the Dow Jones Islamic Market Index (DJMI) and FTSE Global Islamic Index Series, followed by the Malaysian Kuala Lumpur Shari’ah Index, has been a turning point for the industry, giving both Islamic and conventional investors something with which to compare.

The Dow Jones Islamic Market Index, for example, started with 600 companies in 30 countries, down from 3,000 before the religious screening process. The Dow Jones performed more than 50 Islamic indices that track industries which are compliant with Islamic laws (Hussein \& Omran, 2005). This is also due to the sha'riah principles allow IMF to be more resilient than CMF during economic crisis where the independence of Islamic capital market has acted as a cushion to protect from financial crisis (Alrashidi, 2013). Other researchers (Ismail \& Shakrani, 2003) find IMF exposes to a lower degree of risk than CMF at the whole period by using the Capital Asset Pricing Model (CAPM) as a benchmarking in return performance.

Moreover, Islamic fund's portfolio similarly developed from both of the security categories; equity, bonds balances or money market. The Islamic equity fund takes after the shari'ah standards and helps investors that do not possess a huge amount of funds to do diversification. Researchers (e.g., Abdullah, Hassan, \& Mohamad, 2007; Alhenawi, Hassan, \& Merdad, 2010; Kräussl \& Hayat, 2008) claimed that shari’ah compliant mutual funds tend to outperform the CMFs amid financial crisis, due to its nature which is relatively less risky and more secured than CMFs during overall bullish periods; CMFs tend to perform better than IMFs. Even though, there is widely-spread global acceptance of IMFs today; there still remains inconclusive which financial instruments have better performance.

\section{The Research Objectives}

Over the years, the number of IMFs has increased from eight in 1991 to 250 mutual funds which are equivalent to US\$3 trillion dollar around the globe today. The IMFs are expected to continuously increase up to US $\$ 4$ trillion in the year 2020s. Whilst the shari'ah financial industry is gaining momentum, the global conventional financial industry on the contrary is facing a significant breakdown of value by US\$16 trillion during the crisis period (2007-2008) - providing opportunities for Islamic capital market to play a crucial role in driving global asset growth (SCM, 2009). This will be an alternative approach for investors, who are interested to invest and gain return from shari’ah compliant investments (Yuzi, Samsuddin, Shair, \& Hazny, 2012). 
The study of IMFs in Malaysia is very important considering of two main reasons which are the 1997 Asian Financial Crisis and the liquidity problem resulting from surplus funds from the Islamic finance industry (IOSCO, 2004). In particular, the study of IMFs performance in Malaysia is significant considering that it accounts for over 29\% of the global Islamic funds (Mansor, Bhatt, \& Ariff, 2015). Several studies (i.e., Kothari \& Warner, 2001; Elfakhani, Hassan, \& Sidani, 2005; Abdullah, Hassan, \& Mohammad, 2007; Abderrezak, 2008) show major findings that the IMFs outperform CMFs in bearish market. However, the performance of IMFs in relative to CMFs is still questionable in Malaysia with a mixture results from researchers (Albaity \& Ahmad, 2008; Low, 2008; Abdullah \& Abdullah, 2009; Hassan, Khan, \& Ngow, 2010).

This study aims to investigate the comparative performance between IMFs and CMFs during the whole period (2007-2015) and the financial crisis (2007-2009), mainly in Malaysia. The sample covers the monthly data from 200 mutual funds (100 IMFs and $100 \mathrm{CMFs}$ ) covering all categories of equity funds. The performance will be measured over a 9-year period (2007-2015) and compared during financial crisis (2007-2009). The data will be evaluated based on two standard performance measures, namely Sharp Ratio and Jensen's Alpha. The study also will create some avenue to the investors of the performance measures in different investment goals return, risk tolerance, liquidity needs, and reasons why investors choose IMFs for their resources (Rao, Tauni, \& Iqbal, 2015).

\section{Review of Previous Studies}

The study of mutual fund performance between the IMFs and CMFs is considered from different analysis which are risk and return analysis, performance persistency within stock market towards the performance of mutual funds and performance measurement against market benchmark. However, research on Islamic mutual funds, is limited despite of the growing interest on Islamic mutual funds in this global phenomenon (Alhenawi, Hassan, \& Merdad, 2010); Table 1 summaries the previous studies on conventional mutual funds and Islamic mutual funds inclusive of the data used, research methodology, and findings extracted in the various studies. 
Table 1

Previous Studies on Mutual Funds (CMFs and IMFs)

\begin{tabular}{|c|c|c|c|}
\hline Study & Data & \begin{tabular}{|l|} 
Research \\
Methodology
\end{tabular} & Findings \\
\hline \multicolumn{4}{|c|}{ Previous Studies on Conventional Mutual Funds } \\
\hline McDonald, 1974 & $\begin{array}{l}123 \text { mutual funds, American-monthly } \\
\text { data extracted from } 1960 \text { to } 1979 \text {. }\end{array}$ & $\begin{array}{l}\text { Sharpe Ratio, Treynor Ratio, } \\
\text { Jensen's Alpha }\end{array}$ & $\begin{array}{l}\text { Mutual funds studied typically did not outperform market } \\
\text { index. (NYSE) }\end{array}$ \\
\hline Kon \& Jen, 1979 & $\begin{array}{l}49 \text { mutual funds, monthly data extracted } \\
\text { from } 1960 \text { to } 1971 .\end{array}$ & Standard Regression & $\begin{array}{l}\text { Multiple levels of beta indicated; exhibiting market timing's } \\
\text { impression. }\end{array}$ \\
\hline Kon, 1983 & $\begin{array}{l}49 \text { mutual funds, monthly data extracted } \\
\text { from } 1960 \text { to } 1971 .\end{array}$ & Standard Regression & $\begin{array}{l}\text { Stock selection generally indicated statistically significant } \\
\text { findings; timing performance generally exhibited } \\
\text { insignificant positive results. }\end{array}$ \\
\hline $\begin{array}{l}\text { Chen, Cheng, } \\
\text { Rahman, \& } \\
\text { Chan, } 1992 \\
\end{array}$ & $\begin{array}{l}93 \text { mutual funds, data extracted from } \\
1977 \text { to } 1984 .\end{array}$ & Quadratic Market Model & $\begin{array}{l}\text { The trade-off between market timing and security selection } \\
\text { skills; the inability of skills by managers in market timing. }\end{array}$ \\
\hline $\begin{array}{l}\text { Annuar, Shamsher, \& } \\
\text { Ngu, } 1997\end{array}$ & $\begin{array}{l}31 \text { mutual funds, Malaysian-data } \\
\text { extracted from } 1990 \text { to } 1995 .\end{array}$ & Treynor Ratio, Mazuy Model & $\begin{array}{l}\text { Traces of positive selectivity performance and inverse } \\
\text { timing performance indicated, as well as direct indication of } \\
\text { the link between selectivity and timing performance. }\end{array}$ \\
\hline $\begin{array}{l}\text { Shamsher, Annuar, \& } \\
\text { Taufiq, } 2000\end{array}$ & $\begin{array}{l}41 \text { mutual funds, active and passively } \\
\text { managed in Malaysia—1995 to } 1999 .\end{array}$ & $\begin{array}{l}\text { Sharpe Ratio, Treynor Ratio, } \\
\text { Jensen’s Alpha }\end{array}$ & $\begin{array}{l}\text { Results indicate no difference in the link with actively and } \\
\text { passively managed funds; and that funds underperformed the } \\
\text { market portfolio as well as lower levels of diversification. }\end{array}$ \\
\hline \multicolumn{4}{|c|}{ Previous Studies on Islamic Mutual Funds } \\
\hline Hassan (2001) & $\begin{array}{l}\text { DJIM, Dow Jones Islamic Market Index } \\
1996-2000 .\end{array}$ & $\begin{array}{l}\text { correlation, variance ratio, and } \\
\text { Dickey Fuller tests GARCH }\end{array}$ & $\begin{array}{l}\text { Serial framework DJIM returns are normally distributed and } \\
\text { efficient. Significant positive relationship between } \\
\text { conditional volatility and DJIM equity index returns. }\end{array}$ \\
\hline $\begin{array}{l}\text { Hakim \& Rashidan, } \\
2002\end{array}$ & $\begin{array}{l}\text { Sample data of DJI, Wilshire } 5000 \\
\text { index-monthly data extracted from } \\
1999-2002 .\end{array}$ & $\begin{array}{l}\text { Test for Causality; Co-integration } \\
\text { Analysis }\end{array}$ & $\begin{array}{l}\text { Islamic funds exhibit unique risk-return characteristics bar } \\
\text { any influence from broad equity market; no correlation } \\
\text { detected. }\end{array}$ \\
\hline $\begin{array}{l}\text { Hakim \& } \\
\text { Rashidian, } 2004\end{array}$ & \begin{tabular}{|l|} 
Shariah-compliant index (DJIM), Dow \\
Jones World Index (DJW), and Dow \\
Jones Sustainability World Index (DJS). \\
\end{tabular} & $\begin{array}{l}\text { Capital Asset Pricing Model } \\
\text { (CAPM) }\end{array}$ & $\begin{array}{l}\text { DJIM has done relatively well compared to the DJW, but has } \\
\text { underperformed the DJS. }\end{array}$ \\
\hline Hussein (2005) & $\begin{array}{l}\text { DJIM returns } \\
1996-2003 .\end{array}$ & $\begin{array}{l}\text { a comprehensive study capturing } \\
\text { the effects of industry, size, and } \\
\text { economic conditions }\end{array}$ & $\begin{array}{l}\text { Islamic indexes provide investors with positive abnormal } \\
\text { returns throughout the entire bull period, but they } \\
\text { under-perform their non Islamic index counterparts during } \\
\text { the bear market period. Concludes that abnormal returns are } \\
\text { driven by investing in small size, basic material, consumer } \\
\text { cyclical, industrial and telecommunication firms. }\end{array}$ \\
\hline
\end{tabular}


(table 1 continued)

\begin{tabular}{|c|c|c|c|}
\hline Study & Data & \begin{tabular}{|l} 
Research \\
Methodology
\end{tabular} & Findings \\
\hline $\begin{array}{l}\text { Elfakhani, Hassan, \& } \\
\text { Sidani, } 2005\end{array}$ & $\begin{array}{l}46 \text { Islamic mutual funds, monthly data } \\
\text { extracted from 1997-2002. }\end{array}$ & $\begin{array}{l}\text { Sharpe Ratio, Treynor Ratio, } \\
\text { Jensen’s Alpha, one-way ANOVA } \\
\text { test }\end{array}$ & $\begin{array}{l}\text { No indication of difference in behavior of IMF than that of } \\
\text { CMF; with indications of stronger performance of IMF } \\
\text { during the economical bust period. }\end{array}$ \\
\hline $\begin{array}{l}\text { Abdullah, Hassan, \& } \\
\text { Mohamad, } 2007\end{array}$ & $\begin{array}{l}\text { 65 equity-based funds-14 IMFs and } 51 \\
\text { CMFs, monthly data extracted from } \\
1992 \text { to } 2001 .\end{array}$ & $\begin{array}{l}\text { Sharpe Ratio, Jensen’s Alpha, } \\
\text { Modigliani Measure }\end{array}$ & $\begin{array}{l}\text { IMF typically illustrates better performance during bearish } \\
\text { climate; and vice versa in bullish climates. Stock selection } \\
\text { and timing performance indicate poor results for both cases. }\end{array}$ \\
\hline Abderrezak, 2008 & $\begin{array}{l}46 \text { Islamic mutual funds, data extracted } \\
\text { from } 1997 \text { to } 2002 \text {. }\end{array}$ & $\begin{array}{l}\text { Sharpe Ratio, One Factor Model, } \\
\text { Fama measures of Diversification }\end{array}$ & $\begin{array}{l}\text { Results indicate low correlation between IMF returns and } \\
\text { market returns, translated by low beta, and low } \\
\text { diversification indicated by IMF with regard for firm size } \\
\text { and growth. }\end{array}$ \\
\hline Merdad et al., 2010 & $\begin{array}{l}28 \text { mutual funds, monthly net asset } \\
\text { values; Saudi Arabia—data extracted } \\
\text { from } 2003 \text { to } 2010 .\end{array}$ & $\begin{array}{l}\text { Sharpe Ratio, Treynor Ratio, } \\
\text { Jensen's Alpha }\end{array}$ & $\begin{array}{l}\text { IMF typically illustrates better performance during bearish } \\
\text { climate; and vice versa in bullish climates; exhibiting } \\
\text { hedging opportunities supported by shari'ah allowances } \\
\text { during economic downturn. }\end{array}$ \\
\hline $\begin{array}{l}\text { Hoepner, Rammal, \& } \\
\text { Rezec, } 2011\end{array}$ & $\begin{array}{l}\text { Sample of } 262 \text { Islamic equity funds from } \\
20 \text { countries and } 4 \text { regions from } 1990 \text { to } \\
2009 .\end{array}$ & $\begin{array}{l}\text { One factor model, Fama and } \\
\text { French (1993), Three factor model, } \\
\text { Cahart (1997) models. }\end{array}$ & $\begin{array}{l}\text { Islamic funds display superior learning in more developed } \\
\text { Islamic Financial markets. Islamic funds are competitive to } \\
\text { international equity benchmarks. }\end{array}$ \\
\hline $\begin{array}{l}\text { Mansor \& Bhatti, } \\
2011\end{array}$ & $\begin{array}{l}\text { Monthly returns for } 129 \text { Malaysian IMFs } \\
\text { of various categories from } 1990 \text { to } 2009 .\end{array}$ & $\begin{array}{l}\text { Comparative analysis of returns, } \\
\text { panel Ordinary Least Squares } \\
\text { (OLS), CAPM }\end{array}$ & $\begin{array}{l}\text { Risk-return relationship of debt IMFs is relatively stable in } \\
\text { comparison to asset allocation and equity IMFs. Statistically } \\
\text { insignificant difference in return performance of IMFs to } \\
\text { single and multiple benchmarks (i.e., returns are comparable } \\
\text { to the market benchmark). }\end{array}$ \\
\hline $\begin{array}{l}\text { Hayat \& Kraeussl, } \\
2011\end{array}$ & $\begin{array}{l}145 \text { Islamic mutual funds, data extracted } \\
\text { from } 2000 \text { to } 2009 \text {. }\end{array}$ & $\begin{array}{l}\text { Sharpe Ratio, Treynor Ratio, } \\
\text { CAPM Analysis, Modigliani } \\
\text { measure }\end{array}$ & $\begin{array}{l}\text { General underperformance of IMF relative to both } \\
\text { benchmarks; with enhanced effects during recessionary } \\
\text { period. Indication of poor market timing and selection in } \\
\text { IMF. }\end{array}$ \\
\hline Dewi \& Ferdian, 2012 & $\begin{array}{l}14 \text { and } 10 \text { Islamic mutual funds; } \\
\text { Malaysia and Indonesia } \\
\text { respectively-data extracted from } 2006 \\
\text { to } 2009 .\end{array}$ & $\begin{array}{l}\text { Sharpe Ratio, Treynor Ratio, } \\
\text { Jensen's Alpha }\end{array}$ & $\begin{array}{l}\text { Malaysian IMF performance illustrates better results than } \\
\text { Indonesian IMF; in both recessionary and normal conditions. } \\
\text { Market timing does not appear to have a substantial impact } \\
\text { on overall returns. }\end{array}$ \\
\hline $\begin{array}{l}\text { Razzaq, Gul, Sajid, \& } \\
\text { Mughal, } 2012\end{array}$ & 9 Pakistan 2009-2010. & Sharpe Ratio & $\begin{array}{l}\text { Pakistan Islamic funds are growing and investors are } \\
\text { attracted by these funds. The returns of mutual funds are } \\
\text { according to their level of risk. }\end{array}$ \\
\hline $\begin{array}{l}\text { Merdad \& Hassan, } \\
2013\end{array}$ & $\begin{array}{l}143 \text { Islamic mutual funds; Saudi } \\
\text { Arabia-data extracted from } 2004 \text { to } \\
2010 .\end{array}$ & $\begin{array}{l}\text { Sharpe Ratio, Treynor Ratio, Net } \\
\text { Asset Value measure, Modigliani } \\
\text { measure }\end{array}$ & $\begin{array}{l}\text { Results indicate sensitivity to varying demographics; IMF } \\
\text { typically illustrates better performance during bearish } \\
\text { climate; and vice versa in bullish climates-domestic funds } \\
\text { are less sensitive to recessionary pressure than foreign } \\
\text { counterparts. }\end{array}$ \\
\hline
\end{tabular}


(table 1 continued)

\begin{tabular}{|c|c|c|c|}
\hline Study & Data & $\begin{array}{l}\text { Research } \\
\text { Methodology }\end{array}$ & Findings \\
\hline $\begin{array}{l}\text { Karim, Datip, \& } \\
\text { Shukri, } 2014\end{array}$ & $\begin{array}{l}\text { Daily closing of Malaysia Dow Jones } \\
\text { Islamic Index (DJIM) and FSTE Bursa } \\
\text { Malaysia Index (KLCI) from January } \\
2000 \text { to December } 2011 \text { to represent both } \\
\text { the Islamic and conventional stock } \\
\text { markets. }\end{array}$ & $\begin{array}{l}\text { Sharpe Ratio, Treynor Ratio, } \\
\text { Adjusted Jensen’s } \\
\text { Alpha Index Performance and } \\
\text { Modified Sharpe Ratio }\end{array}$ & $\begin{array}{l}\text { Islamic stock market versus conventional stock market. } \\
\text { International Journal of Economics, Commerce and } \\
\text { Management, 2(11), 1-9. }\end{array}$ \\
\hline Arshad \& Rizvi, 2014 & \begin{tabular}{|l|}
4 Conventional Indices and 5 Islamic \\
Indices-data extracted from period of \\
12 years from January 3, 2000 to \\
December 30,2011 , a total observation \\
with points of 3130 day. \\
\end{tabular} & $\begin{array}{l}\text { Multivariate General } \\
\text { Autoregressive Conditional } \\
\text { Hetroskedasticity } \\
\text { Dynamic Conditional Correlation } \\
\text { (MGARCH) DCC method } \\
\end{array}$ & $\begin{array}{l}\text { Research shows strong evidence that conditional } \\
\text { correlations between Islamic Indices and conventional } \\
\text { financial indices show a negative trend during the times of } \\
\text { recent crisis. }\end{array}$ \\
\hline $\begin{array}{l}\text { Majdoub \& Mansour, } \\
2014\end{array}$ & $\begin{array}{l}6 \text { countries MSCI index comparisons } \\
\text { with daily stock market return. }\end{array}$ & $\begin{array}{l}\text { Multivariate MGARCH model is } \\
\text { utilized with constant conditional } \\
\text { correlation of Bollerslev (1990) } \\
\text { and the multivariate GARCH } \\
\text { model with the dynamic } \\
\text { conditional correlation of Engle } \\
(2002)\end{array}$ & $\begin{array}{l}\text { Research highlights correlation Islamic daily stocks return in } \\
\text { various Islamic countries with market indexes. The return } \\
\text { volatility of the Turkish market is the highest. }\end{array}$ \\
\hline
\end{tabular}


Based on Table 1, most of the previous studies primarily applied three models to measure the performance of portfolio. Those methods are similarly with McDonald (1974) which indicated that majority of the mutual fund did not outperform the New York Stock Exchange (NYSE) Index. McDonald used Sharpe Ratio (Sharpe, 1966), Treynor Ratio (Treynor \& Mazuy, 1966), and Jensen’s Alpha (Jensen, 1968) to measure the performance of 123 mutual funds using monthly data from 1960 to 1969.

The classic theory by Jensen (1969) showed an absolute measure of performance based upon the Capital Asset Pricing Model and reported that mutual funds did not appear to achieve abnormal performance when transaction costs were taken into account. The concept of Islamic mutual funds was initiated in 1990s and the initial studies on Islamic mutual funds were conducted to assess 31 Malaysian mutual funds by using Treynor and Mazuy model (1966) for the period 1990-1995 (Annuar, Mohamed, \& Ngu, 1997). The study concluded that Malaysian mutual fund outperforms their benchmark but the market timing was poor. Researchers found on Islamic stock investment under Kuala Lumpur Shari'ah Index (KLSI) marginally underperformed Kuala Lumpur Composite Index (KLCI). The risk-adjusted returns and beta for KLCI were higher relative to KLSI which has lower risk-adjusted returns and beta in the short run (Mansor \& Bhatti, 2011). Other researchers (i.e., Bauer, Otten, \& Rad, 2006; Hassan \& Girard, 2011) applying the Sharpe, Treynor, and Jensen methods to measure the return performance, found no significant difference in performance between Islamic and conventional indices and that both groups are poorly integrated. Similar reward to risk and diversification benefits also exist for both set of indices.

\section{Performance Measurement}

\section{Data Analysis}

This section comprises the descriptive statistics and performance measurements of the chosen 100 IMFs and 100 CMFs in relative to their respective benchmarks which are Shariah Index and KLCI Index. The analysis was conducted based on the monthly returns data during two sample periods which is the whole period (2007 to 2015) and the financial crisis period (2007 to 2009) and the three-month Malaysian Treasury bill served as the risk-free rate benchmark. This would allow for the comparison of the performance of the Islamic unit trusts against the equity market and risk-free rate performances. All data information were obtained from Bloomberg, Kuala Lumpur Composite Index, FTSE Bursa Malaysia EMAS Shariah Index.

\section{Sharpe Ratio}

Origins theory from Sharpe (1966), Sharpe Ratio is developed to measure the relationship between the standard deviation of return and the average excess return (risk premium). Modigliani and Modigliani (1997) stressed that Sharpe Ratio is one of the most accurate measurements that widely employed for determining the return and risk-adjustment performance of the portfolio. If the value results in positive or exceeding zero, it means that the investment is worthy whereas the negative Sharpe Ratio which stipulates the return of investment is lower than it's risk-free rate. The following measures were used to evaluate the Islamic and conventional mutual fund.

\section{Jensen's Alpha}

Jensen's Alpha is used to measure the returns of the portfolio on a basis of risk-adjusted by taking the market 
performance as the benchmark. Origins from Jensen (1968) who derived a risk-adjusted measuring the performance of portfolio evaluates the predictive ability of fund managers in returns of the funds. Jensen's Alpha assesses the systematic risks relative to the values of expected returns. It is also used to determine the excess return of a portfolio over the portfolio's theoretical expected return or risk adjusted return, predicted by the CAPM. A positive alpha indicates the fund managers of portfolio have superior skills on selectivity and management (Alhenawi, Hassan, \& Merdad, 2010). Overall, the two standard methods namely the Sharpe's Index and Jensen's Alpha Index are employed to evaluate the performance of IMFs and CMFs as market benchmarks.

\section{Selected Mutual Funds by Financial Institutions}

On Bursa Malaysia, nearly 90 percent of the listed securities are Shariah compliant. These stocks account for two-thirds of the stock market capitalization and 70 percent of the broad equity index known as FTSE Bursa Malaysia EMAS Index (Krasicka \& Nowak, 2012). This study used 100 IMFs and 100 CMFs from three categories by financial institutions which are Mutual Unit Trust Corporation (MUTC), Investment Banks, and Insurance Companies. Overall percentages by categories are almost equal for both mutual funds. Figure 1 illustrates the CMFs and Figure 2 illustrates the IMFs by financial institutions.

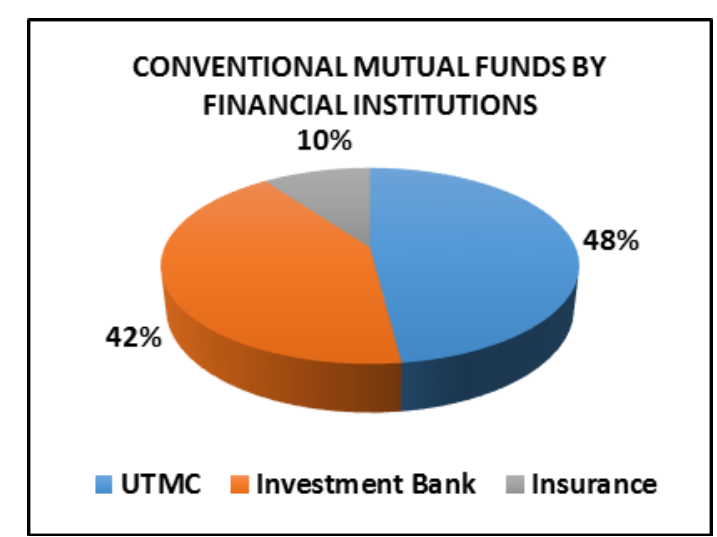

Figure 1. Conventional mutual funds by financial institutions.

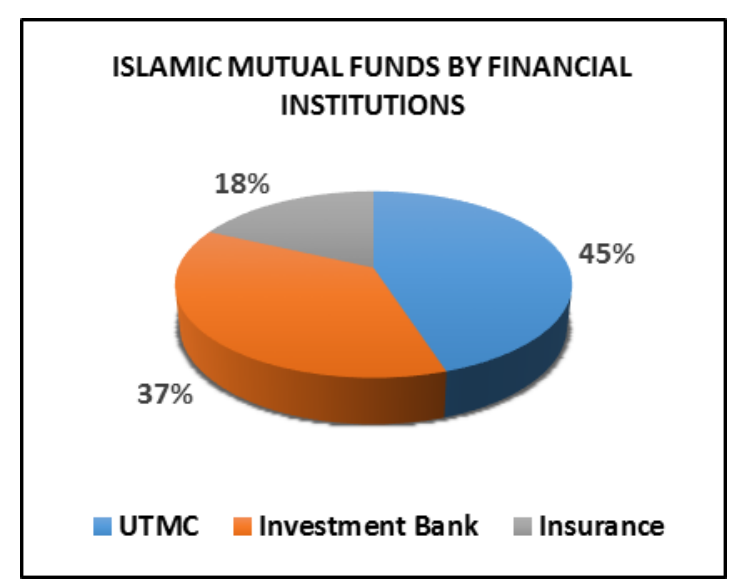

Figure 2. Islamic mutual funds by financial institutions. 


\section{Results and Discussions}

\section{Descriptive Statistics}

Mean. Table 2 shows the average performance of selected IMFs and CMFs from 2007 to 2015 (the whole period) and from 2007 to 2009 (during crisis period). The average mean returns of both IMFs and CMFs performed above the respective benchmarks (i.e., Shariah Index and KLCI Index) by entire sample period (2007-2015) by around 93\% and 32\% respectively. During the crisis period (2007-2009), the mean returns for CMFs are $15 \%$ which is lower than IMFs. The return of both funds is lower implying that the portfolios affected by the economic crisis. Literally, the average returns from the selected CMFs were both negative in the entire sample periods (both periods). Unlike the selected IMFs it showed negative return for the whole period (2007-2015). This phenomenon indicates that the investors' capitals from CMFs could not earn a minimum return of risk-free return, yet their capitals averagely shrunk over the both periods. However, the mean returns of average CMFs for the whole period (2007-2015) were still higher (less negative) than IMFs average mean returns.

Table 2

Average Performance of IMFs and CMFs With Market Benchmark

\begin{tabular}{|c|c|c|c|c|}
\hline \multirow{3}{*}{ Mean } & \multicolumn{4}{|c|}{ Average mean returns of IMFs and CMFs with market benchmark } \\
\hline & \multicolumn{2}{|l|}{ Portfolio } & \multicolumn{2}{|c|}{ market benchmark } \\
\hline & $2007-2015$ & 2007-2009 & $2007-2015$ & 2007-2009 \\
\hline CMFs & 0.20 & 0.12 & -0.0341 & -0.0339 \\
\hline \multirow[t]{2}{*}{ IMFs } & 0.57 & 0.18 & -0.0351 & -0.0373 \\
\hline & \multicolumn{4}{|c|}{ Average standard deviation of IMFs and CMFs with market benchmark } \\
\hline \multicolumn{5}{|l|}{ Standard deviation } \\
\hline CMFs & 1.93 & 2.18 & 0.0386 & 0.0557 \\
\hline \multirow[t]{2}{*}{ IMFs } & 2.20 & 2.51 & 0.0409 & 0.0582 \\
\hline & \multicolumn{4}{|c|}{ Average Sharpe Ratio of IMFs and CMFs with market benchmark } \\
\hline \multicolumn{5}{|l|}{ Sharpe Ratio } \\
\hline CMFs & -0.41 & -0.23 & -0.8823 & -0.6078 \\
\hline \multirow[t]{2}{*}{ IMFs } & -0.42 & -0.22 & -0.8578 & -0.6402 \\
\hline & \multicolumn{4}{|c|}{ Average Jensen's Alpha of IMFs and CMFs with market benchmark } \\
\hline \multicolumn{5}{|l|}{ Jensen’s Alpha } \\
\hline CMFs & -0.18 & -0.10 & -0.0421 & 0.0219 \\
\hline IMFs & -0.39 & -0.07 & -0.0391 & 0.0161 \\
\hline
\end{tabular}

Standard deviation. Standard deviation is an absolute risk measure used to indicate the total risk portfolio (Haber \& Braunstein, 2016). Overall, the data show significantly higher standard deviation during the crisis for both CMFs and IMFs which implies a greater risk during that particular period in relative to the whole sample period. In relation to the dispersion risk, the data show that the average standard deviation of IMFs was higher than the CMFs and market benchmark for both periods which are 22.0\% (2007-2015) and 25.1\% (2007-2009) respectively. This shows the volatility of average return of the IMFs was higher than the volatility of average return of the market. Similar condition with the CMFs, the average standard deviation of CMFs was higher than the market benchmarks which point 19.3\% (2007-2015) and 21.8\% (2007-2015). This could be explained that IMFs average return was more volatile than the market. Notably, the presence of outlier of certain funds 
contributed to the higher standard deviation value of the average IMFs in both periods. Furthermore, IMFs were observed to be significantly much more volatile than CMFs while their standard deviations in both periods were 1.14 to 1.15 times higher than CMFs. It could be inferred that IMFs had greater volatility than CMFs. The different risk profile between IMFs and CMFs explains the different return performance. The higher standard deviation shows the greater the performance of mutual funds which encourage the inflow of short-term capital. This short-term capital is highly volatile and is also vulnerable to global shock (Majdouba \& Mansour, 2014).

\section{Jensen's Alpha}

Jensen's Alpha is performed to measure the portfolio's total return and the amount of risk involved in achieving the return, using CAPM (Jensen, 1968). Jensen's Alpha is a measure of risk adjusted return compared to the market index based on the CAPM. The investors will opt for portfolio with positive alphas as a signal of higher return with minimum level of risk. Jensen's Alpha is also a tool to measure how much the portfolio signal outperformed the market return as a benchmark. The higher the value of Jensen Alpha, the more superior selectivity skills of investment managers against the benchmark (Kim, 2013). In this study, Jensen's Alpha of IMFs shows slightly higher (-0.07) than CMFs $(-0.10)$ during crisis period. This scenario reflected that the average Islamic funds have outperformed their respective market index from 2007-2015. This is also because of Islamic funds during crisis which were buffeted from the effects of the crisis due to their resilience making them able to outperform their benchmark index strongly (Abdullah, Mohamad, \& Hassan, 2007). The results of this study does indicate most of the investors following the Islamic indices, who would be better protected in times of economic crisis originating from financial sector, as well as being in line with Shariah compliance and Halal investments.

\section{Sharpe Ratio}

A negative Sharpe Ratio implies that the fund average returns were lesser than the risk free rate and fund managers were not able to tolerate risk over each unit of risk spread while managing those funds to yield returns. The average Sharpe Ratio of IMFs is -0.22 which is less than in CMFs funds $(-0.23)$ during the crisis period. This scenario signaled that IMFs were riskier during that period but investors of the fund were greatly compensated for bearing the risk than the Islamic funds holders. In addition, the performance of both mutual funds can be summarized in the Table 3.

Table 3

Summary of Results

\begin{tabular}{llllll}
\hline Measurement & IMFs & \multicolumn{3}{l}{ CMFs } & Findings \\
\cline { 2 - 5 } & W. Period & Crisis & W. Period & Crisis & \\
\hline Mean & 0.57 & 0.18 & 0.20 & 0.12 & Whole Period IMFs \\
Std deviation & 2.20 & 2.51 & 1.93 & 2.18 & Whole Period IMFs \\
Sharp Ratio & -0.42 & -0.22 & -0.41 & -0.23 & Crisis Period IMFs \\
Jensen's Alpha & -0.39 & -0.07 & -0.18 & -0.10 & Crisis Period IMFs \\
\hline
\end{tabular}

This study shows that most of IMFs perform less negative and better performance by using Sharpe Ratio and Jensen's Alpha. The results from above imply that IMFs are less affected by the market movement during crisis period. The diversification of IMFs with variety types of funds shows positive results regardless of different 
market conditions. The above result shows that IMFs are less affected by the market movement during financial market. Israelsen (2010) stated that negative excess return will result in negative Sharpe Ratio, which somehow can be stand intuitive higher Sharpe Ratio measures, better performance of mutual funds (Mansor, Bhatti \& Khan 2012).

However, the discrepancy in results may also be attributed to external factor such as interest rate. The rise of interest rate can reduce capital invested due to the increasing of borrowings. During crisis period, Malaysia interest rates faced sharp decline by $1.5 \%$. Practically, this will encourage enterprises to increase their investment due to lower borrowing cost and lead to higher investment. However, even though the interest rate declined, there is no effect on IMFs due to fragile Riba system.

Overall performance, IMFs performed better than CMFs during crisis period. There are several reasons why the IMFs show better performance during crisis period. According to CIMB (2013), during world financial crisis, many investors were looking for fixed income securities with high rate of return and this made sukuk securities more preferable than the bonds in US Treasuries because the rate of return of US Dollar was higher than the US Treasuries.

The results performance of IMFs also can be compared with MSCI Malaysia Islamic Index which reflects Sharia investment principles and is designed to measure the performance of the large and midcap segments of the Malaysian market that are relevant for Islamic investors. From year 2007 to 2015, the MSCI Malaysia Islamic Index performed average annual return performance 13.27\% (MSCI Malaysia Islamic Index).

\section{Inference}

\section{Conclusions}

Overall performance for both IMFs and CMFs shows slightly difference in terms of average return, standard deviation, Sharpe ratio and Jensen Alpha. Even though both IMFs and CMFs outperform higher than market benchmark, IMFs performed slightly better performance than CMFs for both periods.

\section{Limitations and Direction for Future Research}

The authors certain that it is extremely importance that the study has the limitations and needs some adjustments for further research. Thus, the following limitations exist in our study:

1. The duration of the study spans nine years, and was divided into two sub samples period (2007-2015) and crisis period (2007-2009). The study also needs encompassing previous decades which would make the study more robust.

2. The data selection could be biased due to randomly selected. Future research should include panel data analysis for better results.

3. The selection of data could be expanded by using focusing on industries and selected financial institutions.

4. Our research has taken a sample of 200 (100 IMFs and 100 CMFs) from Malaysian equity market. In addition of further research, more data selection should be included from other regions and countries specific indices of the similar methodology. 


\section{References}

Abdullah, F., Hassan, T., \& Mohamad, S. (2007). Investigation of performance of Malaysian Islamic unit trust funds: Comparison with conventional unit trust funds. Managerial Finance, 33(2), 142-153.

Abdullah, F., Mohamed, S., \& Hassan, T. (2002). A comparative performance of Malaysian Islamic and conventional mutual funds. Pertanika, 8(2), 30-49.

Abdullah, N. A., \& Abdullah, N. A. H. (2009). THE performance of Malaysian unit trusts investing in domestic versus international markets. Asian Academy of Management Journal of Accounting and Finance, 5(2), 77-100.

Albaity, M., \& Ahmad, R. (2008). Performance of Syariah and composite indices: Evidence from Bursa Malaysia. Asian Academy of Management Journal of Accounting and Finance, 4(1), 23-43.

Alhenawi, Y., Hassan, M. K., \& Merdad, H. (2010). Islamic versus conventional mutual fund performance in Saudi Arabia: A case study. Journal of King Abdulaziz University: Islamic Economics, 23(2), 163-200.

Alrashidi, F. (2013). Comparison of the performance of Islamic mutual funds vs. ethical and conventional mutual funds. Journal of Finance, 48, 57-78.

Arshad, S., \& Rizvi, S. A. R. (2014). An empirical study of Islamic equity as a better alternative during crisis using multivariate GARCH DCC. Islamic Economic Studies, 22(1), 159-184.

Annuar, M. N., Mohamed, S., \& Ngu, M. H. (1997). Selectivity and timing: Evidence from the performance of Malaysian unit trusts. Pertanika, 5(1), 45-57.

Bauer, R., Otten, R., \& Rad, A. T. (2006). Ethical investing in Australia: Is there a financial penalty? Pacific Basin Finance J., 14, (1),33-48.

CIMB. (2013). Global sukuk market to withstand bond market volatility. Retrieved from http://www.cimb-principalislamic.com/Thought_Leadership-@Global_Sukuk_Market_to_Withstand_Bond_Market_Volatili ty.aspx

Cohen, K. J., \& Pogue, J. A. (1967). An empirical evaluation of alternative portfolio-selection models. The Journal of Business, 40(2), 166-193.

Dietz, P. O. (1966). Pension fund investment performance—-what method to use when. Financial Analysts Journal, 22(1), 83-86.

Elfakhani, S., Hassan, M. K., \& Sidani, Y. (December 2005). Comparative performance of Islamic versus secular mutual funds. In 12th Economic Research Forum Conference in Cairo, Egypt (pp. 19-21).

El-Gamal, M. A. (2000). A basic guide to contemporary Islamic banking and finance (Vol. 1). Houston, TX: Rice University.

Farrar, E. (1962). The investment decision under uncertainty. Englewood Cliffs, New Jersey: Prentice-Hall, Inc.

Friend, I., \& Vickers, D. (1965). Portfolio selection and investment performance. The Journal of Finance, 20(3), 391-415.

Haber, J., \& Braunstein, A. (2016). Forecasting portfolio balance using return mean, standard deviation and spending. International Journal of Financial Research, 7(2), 98-121.

Hassan, M. K., \& Girard, E. (2011). Faith-based ethical investing: The case of Dow Jones Islamic Indexes. Networks Financial Institute Working Paper No. 2011-WP-05. Retrieved on Jan. 13, 2013 from http://ssrn.com/abstract=1808853 or http://dx.doi.org/10.2139/ssrn.1808853

Hassan, M. K., Khan, A. N. F., \& Ngow, T. (2010). Is faith-based investing rewarding? The case for Malaysian Islamic unit trust funds. Journal of Islamic Accounting and Business Research, 1(2), 148-171.

Hoepner, A. G., Rammal, H. G., \& Rezec, M. (2011). Islamic mutual funds' financial performance and international investment style: evidence from 20 countries. The European Journal of Finance, 17(9-10), 829-850.

Horowitz, I. (1965). A model for mutual fund evaluation—mutual funds as investment alternatives. IMR; Industrial Management Review (pre-1986), 6(2), 81.

Hussein, K., \& Omran, M. (2005). Ethical investment revisited: Evidence from Dow Jones Islamic Indexes. The Journal of Investing, 14(3), 105-126.

Ismail, A. G., \& Shakrani, M. S. (2003). The conditional CAPM and cross-sectional evidence of return and beta for Islamic unit trusts in Malaysia. IIUM Journal of Economics and Management, 11(1), 1-30.

Israelsen, R. D. (2010). Investment based valuation and managerial expectations. Available at SSRN 1563502.

IOSCO. (2004). Islamic capital market fact finding report: International Organization of Securities Commission.

Jensen, M. C. (1968). The performance of mutual funds in the period 1945-1964. The Journal of finance, 23(2), 389-416.

Jensen, M. C. (1969). Risk, the pricing of capital assets, and the evaluation of investment portfolios. The Journal of Business, 42(2), 167-247. 
Karim, B. A., Datip, E., \& Shukri, M. H. M. (2014). Islamic stock market versus conventional stock market. International Journal of Economics, Commerce and Management, 2(11), 1-9.

Kassim, S. H., \& Kamil, S. (2012). Performance of Islamic unit trusts during the 2007 global financial crisis: Evidence from Malaysia. Asian Academy of Management Journal, 17(2), 59-78.

Kim, D. (2013). Cognitive communities and legitimacy-based groups: The role of external categorization on cognitive similarity. Academy of Strategic Management Journal, 12(2), 1-32.

Kräussl, R., \& Hayat, R. (2008). Risk and return characteristics of Islamic equity funds. Social Science Research Network (SSRN). Retrieved on August 10, 2017 from http://ssrn.com/abstract=1320712

Kothari, S. P., \& Warner, J. B. (2001). Evaluating mutual fund performance. The Journal of Finance, 56(5), 1985-2010.

Krasicka, O., \& Nowak, S. (2012). What's in it for me? A primeron differences between Islamic and Conventional Finance in Malaysia (No. 12/151). International Monetary Fund.

Lintner, J. (1965). Security prices, risk, and maximal gains from diversification. The Journal of Finance, 20(4), 587-615.

Low, S. W. (2008). A cross-sectional analysis of Malaysian unit trust fund expense ratios. Journal of Asset Management, 9(4), 270-277.

Malaysia, B. N. (2009). Malaysian debt securities and sukuk market. Kuala Lumpur: Bank Negara Malaysia and Securities Commision Malaysia.

Mansor, F., Bhatti, M. I., \& Ariff, M. (2015). New evidence on the impact of fees on mutual fund performance of two types of funds. Journal of International Financial Markets, Institutions and Money, 35(C), 102-115.

Mansor, F., \& Bhatti, M. I. (2009). The performance of Islamic mutual funds: The Malaysian case. In 14th Annual Banking and Finance Conference, Melbourne University, September (Vol. 29).

Mansor, F., \& Bhatti, M. I. (2011). Risk and return analysis on performance of the Islamic mutual funds: evidence from Malaysia. Global Economy and Finance Journal, 4(1), 19-31.

Mansor, F., Bhatti, I., \& Khan, H. (2012, July). Islamic mutual funds performance: A panel analysis. In Second Malaysian Postgraduate Conference (p. 140).

Majdoub, J., \& Mansour, W. (2014). Islamic equity market integration and volatility spillover between emerging and US stock markets. The North American Journal of Economics and Finance, 29(C), 452-470.

McDonald, J. G. (1974). Objectives and performance of mutual funds, 1960-1969. Journal of Financial and Quantitative Analysis, 9(3), 311-333.

Modigliani, F., \& Leah, M. (1997). Risk-adjusted performance. Journal of Portfolio Management, 23(2), 45-54.

Razzaq, N., Gul, S., Sajid, M., \& Mughal, S. (2012). Performance of Islamic mutual funds. Pakistan Economic and Finance Review, 2(3), 16-25.

Rao, Z. U. R., Tauni, M. Z., \& Iqbal, A. (2015). Comparison between Islamic and general equity funds of Pakistan: Difference in their performances and fund flow volatility. Emerging Economy Studies, 1(2), 211-226.

SCM, (2009). Securities Commision Malaysia, Kuala Lumpur Malaysia.

Silva, M. (2006). Islamic banking remarks. Law and Business Review of the Americas, 12(2), 201.

Sharpe, W. F. (1964). Capital asset prices: A theory of market equilibrium under conditions of risk. The Journal of Finance, 19(3), 425-442.

Sharpe, W. F. (1966). Mutual fund performance. The Journal of Business, 39(1), 119-138.

Treynor, J. L. (1965). How to rate management of investment funds. Harvard Business Review, 43(1), 63-75.

Treynor, J. L., \& Mazuy, K. K. (1966). Can mutual funds outguess the markets? Harvard Business Review, 44(4), 131-136.

Yuzi, A., Samsuddin, S., Shair, S. N., \& Hazny, M. H. (September 2012). Performance evaluation of Islamic mutual funds in Malaysia based on asset portfolio. In Statistics in Science, Business, and Engineering (ICSSBE), 2012 International Conference (pp. 1-6). IEEE.

World Bank; Islamic Development Bank Group. 2017. Global Report on Islamic Finance : Islamic Finance - A Catalyst for Shared Prosperity?. Washington, DC: World Bank. (c) Islamic Development Bank Group. Retrieved from https://openknowledge.worldbank.org/handle/10986/25738 License: CC BY 3.0 IGO. 